
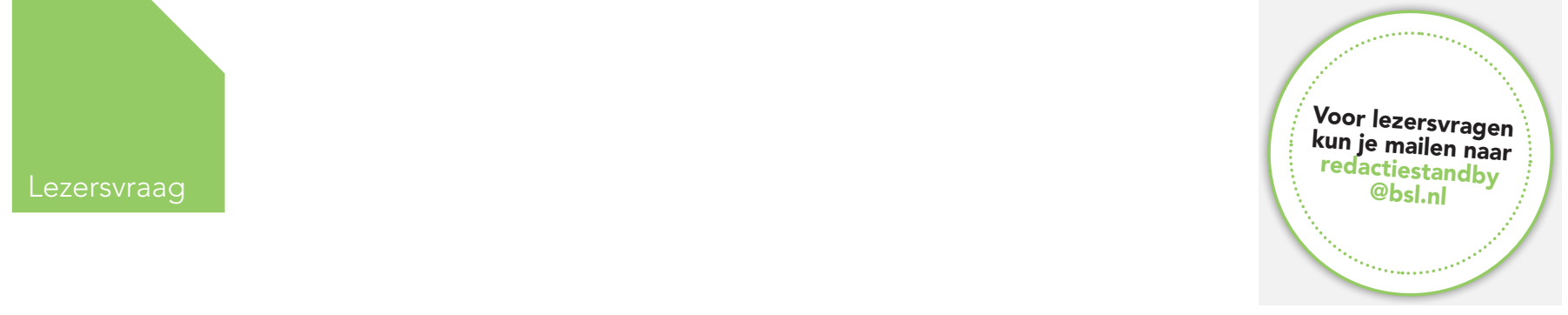

\title{
Wat doe je bij seksuele intimidatie
}

Wat moet je doen als je werkgever seksueel getinte opmerkingen maakt of aan je zit terwijl je dit niet wilt? Helaas komt dit regelmatig voor, ook in tandartspraktijken. Standby ging op zoek naar het antwoord van bovenstaande vragen.

\section{Door Yvonne Maassen}

1

1 at is seksuele intimidatie? Onder seksuele intimidatie vallen alle vormen van seksueel getinte aandacht die ongewenst, eenzijdig en opgelegd is. Het gaat niet om de intentie van de dader, maar om hoe de ontvanger het ervaart. In mijn werk als stagedocent op een opleiding voor tandartsassistenten komt dit ook aan bod. Ik vertel dan altijd een verhaal van 20 jaar

'Hij gaf een klopje op haar knie. Zie je wel', zei de stagiaire' geleden. Een leerling vroeg me om op stagebezoek te komen. Ze voelde zich niet veilig; de tandarts zat steeds aan haar. Ik kreeg van haar de opdracht om hier niets van te zeggen. Toen ik op bezoek kwam, trof ik een hartelijke tandarts aan die supertrots op onze leerling

was. We zaten dicht bij elkaar in een kleine keuken Hij gaf haar een vriendschappelijk klopje op haar knie, terwijl hij me vertelde dat ze het zo goed deed. De leerling echter verstijfde en buiten zei ze: 'zie je wel, hij deed het weer!' Ik dacht: wat een aardige man. Heel erg persoonlijk dus. Door dit verhaal ontstaan er mooie discussies in de klas, maar dit terzijde. De conclusie die hieruit getrokken kan worden, is dat een grens stellen heel erg persoonlijk is. Wat voor de ene persoon een aardig klopje op de knie is, kan voor de ander grensoverschrijdend zijn. In dit verhaal moet de tandarts goed aanvoelen of een klopje op de knie door de leerling als positief ervaren wordt. Er zijn verschillende soorten seksuele intimidatie: - Seksuele intimidatie kan verbaal, zoals seksueel getinte opmerkingen of berichtjes;
- Non-verbaal, zoals staren, seksueel getinte gebaren maken);

- Fysiek, zoals vastpakken, weg versperren. De werkgever moet beleid voeren om seksuele intimidatie te voorkomen en te bestrijden. Zo kan (of moet) de werkgever een vertrouwenspersoon aanstellen waarbij je je verhaal kunt doen. Als je lastig gevallen wordt, moet je duidelijk aangeven dat je niet gediend bent van de opmerkingen of aanrakingen. Mocht het niet stoppen, kun je het beste opschrijven wat en wanneer precies gebeurt. Bespreek met de werkgever of naaste collega wat je is overkomen. Zo sta je er niet alleen voor en zij kunnen ook met iemand buiten je werk (bijvoorbeeld de huisarts of politie) het gesprek aangaan. Er kan een klacht ingediend worden bij de werkgever zodat een onderzoek gedaan kan worden. Mocht dit allemaal niet baten, kun je aangifte doen bij de politie. Maar wat als je in een solopraktijk werkt? Dan sta je er als assistent alleen voor. Ook dan doe je er goed aan om dit met iemand te bespreken. Maak dan ook meteen duidelijk dat je werkgever over jouzu grens gaat. Dat is lastig. Je moet het ook maar durven. Het is wel je werkgever, je broodheer. Wat je altijd kunt doen, is contact met Slachtofferhulp of het Platform Seksuele Intimidatie van Rutgers zoeken. Dit kan anoniem. Verder heeft het ministerie van SZW door TNO het stappenplan Wegrwijzer seksuele intimidatie op het werk laten ontwikkelen.

\section{Bronnen: \\ - WegwijzerSeksueleIntimidatie.pdf \\ - www.slachtofferhulp.nl}

